\title{
ANALISIS PELAKSANAAN PROGRAM PENGAMPUNAN PAJAK (TAX AMNESTY) DI KANTOR PELAY ANAN PAJAK (KPP) PRATAMA SINGARAJA
}

\author{
Putu Gede Septia Widana ${ }^{1}$, Lulup Endah Tripalupi ${ }^{2}$, lyus Akhmad Haris ${ }^{3}$ \\ Program Studi Pendidikan Ekonomi \\ Universitas Pendidikan Ganesha \\ Singaraja, Indonesia \\ e-mail: widianaseptia@gmail.com ${ }^{1}$, endah.tripalupi@undiksha.ac.id², \\ iyusharis55@gmail.com³
}

\begin{abstract}
Abstrak
Tujuan penelitian ini adalah untuk mengetahui pelaksanaan program dan tingkat keberhasilan pelaksanaan program pengampunan pajak (tax amnesty) di KPP Pratama Singaraja. Penelitian ini menggunakan pendekatan penelitian kualitatif dengan rancangan deskriptif. Data dikumpulkan dengan metode wawancara dan studi dokumentasi, kemudian di analisis menggunakan analisis deskriptif. Hasil penelitian menunjukkan, pertama prosedur pelaksanaan tax amnesty pada Kantor Pelayanan Pajak Singaraja telah sesuai dengan peraturan yang berlaku yaitu Undang-Undang No.11 Tahun 2016, kendala dari fiskus yaitu rendahnya kesadaran wajib pajak sedangkan kendala dari wajib pajak yaitu kurangnya sosialisasi program tax amnesty dan kedua tingkat keberhasilan pelaksanaan tax amnesty yang diukur dengan rasio efektivitas penerimaan pajak saat diterapkannya Tax Amnesty pada KPP Pratama Singaraja selama tiga periode (Tahun 2016-2017) dinyatakan kurang efektif atau kurang berhasil dalam meningkatkan penerimaan pajak.
\end{abstract}

Kata kunci: analisis, pelaksanaan, tax amnesty

\begin{abstract}
The purpose of this study is to investigate the implementation of the program and the success rate of tax amnesty program implementation (tax amnesty) on STO Singaraja. This study uses a qualitative approach with descriptive design. Data were collected by interview and documentation study, then analyzed using descriptive analysis. The results of the study showed, first the procedure of tax amnesty in the KPP Pratama Singaraja office is in accordance with the prevailing regulations, namely law No. 11 of 2016, the problem of the poatnika of low taxpayer awareness and Problem of taxpayer i.e. lack of socialization of tax amnesty program and second The success rate of the tax amnesty that is measured by the ratio of the effectiveness of taxes received by the tax Amnesty at KPP Pratama Singaraja for three periods (year 2016-2017) is considered less effective or less successful in Increase tax acceptance.
\end{abstract}

Keyword: analysis, implementation, tax amnesty

\section{PENDAHULUAN}

Indonesia merupakan salah satu negara berkembang yang sedang menggenjot kegiatan pembangunan nasional. Pembangunan nasional adalah pembangunan yang berlangsung secara terus menerus dan berkesinambungan serta merata di seluruh tanah air yang bertujuan untuk mencerdaskan kehidupan bangsa dan untuk mensejahterahkan rakyat Indonesia secara adil dan merata. Agar tujuan tersebut tercapai maka 
dibutuhkan sumber penerimaan negara yang sangat besar untuk membiayai kelangsungan pembangunan tersebut. Sumber penerimaan negara itu terdiri dari pajak, retribusi, sumbangan, bea dan cukai, iuran dan penerimaan negara bukan pajak, dan penerimaan-penerimaan lainnya. Adapun sumber penerimaan terbesar negara berasal dari sektor pajak.

Pajak merupakan sumber penerimaan negara terbesar dimana pendapatan negara yang berasal dari sektor perpajakan hampir mencapai $80 \%$ dari total penerimaan negara. Hal ini yang kemudian membuat pajak menjadi salah satu sumber penerimaan negara yang sangat penting bagi pelaksanaan dan peningkatan pembangunan nasional yang bertujuan untuk meningkatkan kemakmuran dan kesejahteraan masyarakat. Oleh karena itu sangat diharapkan partisipasi masyarakat untuk ikut berperan aktif memberikan kontribusinya bagi peningkatan pendapatan negara karena pada dasarnya besarnya tingkat penerimaan pajak sangat tergantung pada kontribusi dari wajib pajak tersebut (Supramono dan Damayanti, 2010).

Berkaitan dengan penerimaan pajak dalam beberapa tahun terakhir menunjukkan kecenderungan penurunan penerimaan pajak. Penurunan penerimaan pajak diakibatkan oleh wajib pajak tidak sesuai melaporkan harta yang dimiliki dalam Surat Pemberitahuan Tahunan Pajak Penghasilan. Wajib pajak hanya melaporkan harta mereka yang berada di wilayah Negara Kesatuan Republik Indonesia. Sementara sebagian harta yang dimiliki wajib pajak yang berada diluar wilayah Negara Kesatuan Republik Indonesia belum dilaporkan dalam Surat Pemberitahuan Tahunan Pajak Penghasilan. Hal ini berdampak adanya denda sebagai konsekuensi, hingga sanksi pidana yang mungkin timbul apabila dilakukan pembandingan dengan harta yang telah dilaporkan dalam Surat Pemberitahuan Tahunan Pajak Penghasilan yang bersangkutan. Hal ini merupakan salah satu faktor yang menyebabkan para pemilik harta merasa ragu untuk membawa kembali atau mengalihkan harta mereka dan untuk menginvestasikan dalam kegiatan ekonomi di Indonesia.

Untuk meningkatkan penerimaan pajak tersebut, perlu diciptakan sistem perpajakan yang lebih berkeadilan dan berkepastian hukum. Hal ini didasarkan pada masih maraknya aktivitas ekonomi di dalam negeri yang belum atau tidak dilaporkan kepada otoritas pajak. Aktivitas ekonomi yang tidak dilaporkan tersebut mengusik rasa keadilan bagi para wajib pajak yang telah berkontribusi aktif dalam melaksanakan kewajiban perpajakan karena pelakunya tidak berkontribusi dalam pembayaran pajak. Untuk mencapai target penerimaan dari sektor perpajakan dibutuhkan upaya-upaya yang nyata, serta mengimplementasikan dalam bentuk kebijakan pemerintah.

Pemerintah dalam hal ini Direktorat Jendral Pajak berusaha untuk meningkatkan pertumbuhan ekonomi dan pembangunan nasional serta mengejar target penerimaan pajak yaitu dengan mengeluarkan kebijakan pengampunan pajak (tax amnesty). Menurut Silitonga, (2008) salah satu cara inovatif untuk meningkatkan penerimaan pajak tanpa menambah beban pajak baru kepada masyarakat, dunia usaha dan pekerja melalui program pengampunan pajak (tax amnesty). Pengampunan pajak (tax amnesty) merupakan kebijakan pemerintah yang memberikan penghapusan pajak terutang dengan membayar tebusan dalam jumlah tertentu. Tepat pada tanggal 1 Juni 2016 Presiden Republik Indonesia mengesahkan Undang-Undang Tax Amnesty No. 11 Tahun 2016 tentang Pengampunan Pajak. Pelaksanaan pengampunan pajak (tax Amnesty) merupakan upaya pemerintah untuk menarik sebagian harta warga negara Indonesia yang selama ini ada di luar negeri dan belum dilaporkan dalam Surat Pemberitahuan Tahunan Pajak Penghasilan. Dengan adanya pengampunan pajak (tax amnesty) diharapkan mampu meningkatkan subjek pajak dan objek pajak. Subjek pajak berupa penambahan wajib pajak, sedangkan objek pajak dapat berupa kembalinya dana-dana dari luar negeri. 
Undang-Undang Republik Indonesia No. 11 tahun 2016 tentang Pengampunan Pajak (Tax Amnesty) dapat diikuti oleh semua Wajib Pajak (WP) baik orang pribadi maupun badan, dengan catatan Wajib Pajak (WP) yang sedang dalam proses penyidikan dan telah di $P-21$ dalam proses peradilan atau Wajib Pajak (WP) yang sedang menjalani hukum atas pidana dibidang perpajakan. Pemerintah mempunyai harapan besar terhadap suksesnya program pengampunan pajak (tax amnesty) tahun 2016, dengan program ini Wajib Pajak (WP) orang pribadi maupun badan akan dibebaskan dari segala bentuk sanksi ketika melaporkan aset yang selama ini belum pernah dilaporkan

Wajib Pajak (WP) akan dikenai menyampaikan surat pernyataan pada bulan pertama ampai akhir bulan ketiga (01 Juli-30 September 2016) baik harta yang ada di Indonesia maupun di luar Indonesia tetapi akan dialihkan ke Indonesia, dan 4\% apabila hartanya tidak dialihkan ke Indonesia. Wajib Pajak (WP) akan dikenai 3\% apabila menyampaikan surat pernyataan pada bulan keempat sampai akhir bulan keenam (01 Oktober31 Desember 2016) baik harta yang ada di Indonesia maupun di luar indonesia tetapi akan di alihkan ke Indonesia, dan 6\% apabila hartanya tidak di alihkan ke Indonesia. Wajib Pajak (WP) akan dikenai uang tebusan sebesar $5 \%$ apabila menyampaikan surat pernyataan pada 01 Januari - 31 Maret 2017 baik harta yang ada di Indonesia maupun di luar indonesia tetapi akan di alihkan ke Indonesia, dan $10 \%$ apabila hartanya tidak di alihkan ke Indonesia (UU No. 11 Pengampunan Pajak 2016).

Meskipun pendapatan negara dari sektor pajak paling tinggi dibandingkan dengan sumber lain, tetapi tax ratio Indonesia masih sangat rendah dengan negara lain. Tax ratio adalah alat ukur kemampuan pemerintah dalam mengumpulkan pajak dari masyarakat, semakin tinggi tax ratio semakin efektif kebijakan pengumpulan pajak dapat dijalankan. Semakin tinggi presentase tax ratio, maka semakin tinggi pula kepatuhan
Wajib Pajak (WP) dalam membayar pajak. Tax ratio Indonesia $11 \%$ (www.kemenkeu.go.id, 2016) angka ini masih sangat rendah dibandingkan dengan negara lain.

Di daerah Provinsi Bali khusunya di Kabupaten Buleleng menerapkan program Pengampunan Pajak (Tax Amnesty) yakni di Kantor Pelayanan Pajak Pratama Singaraja. Berhasil atau tidaknya penerapan program tax amnesty ini dalam meningkatkan penerimaan pajak dapat dilihat dari penerimaan pajak sebelum dan sesudah adanya tax amnesty. Jumlah penerimaan pajak sebelum dilakukan program tax amnesty, target penerimaan pajak pada tahun 2014 sebesar $R p$ 267.775.752.000 dan realisasi pajak sebesar Rp 264.997.643.106. Pada tahun 2015 target penerimaan pajak sebesar $\mathrm{Rp}$ 295.665.006.000 dan realisasi penerimaan pajak sebesar Rp 258.180.722.139. Setelah pada tahun 2016 diberlakukan kebijakan tax amnesty, target penerimaan pajak sebesar Rp 384.889.441.702 dan realisasi penerimaan pajak sebesar $\mathrm{Rp}$ 286.142.679.091. Pada tahun 2017 target penerimaan pajak sebesar Rp 363.911.417.007 dan realisasi penerimaan pajak sebesar $\mathrm{Rp} 267.622 .722 .672$, pada tahun 2017 ini realisasi penerimaan pajak mengalami penurunan. Hal ini menunjukkan bahwa penerapan tax amnesty oleh KPP Pratama Singaraja belum berhasil dalam meningkatkan penerimaan pajak. Hal ini tidak sesuai dengan pendapat (Alm. James, 2009) yang menyebutkan bahwa tax amnesty berguna untuk meningkatkan penerimaan pajak dalam jangka pendek, meningkatkan kepatuhan di masa yang akan datang, mendorong repatriasi modal atau aset, transisi menuju sistem perpajakan yang baru.

Berdasarkan pemaparan latar belakang diatas maka tujuan dari penelitian ini adalah untuk mengetahui; (1) pelaksanaan program pengampunan pajak (tax amnesty) di KPP Pratama Singaraja dan (2) tingkat keberhasilan pelaksanaan program pengampunan pajak (tax amnesty) di KPP Pratama Singaraja. 


\section{METODE PENELITIAN}

Penelitian ini dilakukan dengan menggunakan metode kualitatif, dimana peneliti akan melakukan penelitian terhadap fenomena dan observasi langsung ke lapangan serta mengumpulkan data-data yang akan dianalisis berdasarkan pengamatan dan pengetahuan peneliti. Menurut Sugiyono, (2015) pengertian penelitian kualitatif tersebut merupakan penelitian yang digunakan untuk meneliti pada kondisi objek alamiah dimana peneliti adalah instrumen kunci. Penelitian deskriptif kualitatif akan menafsirkan data yang berkaitan dengan kondisi yang terjadi sekarang.

Lokasi pada penelitian adalah KPP Pratama Singaraja Jalan U dayana No 10 Singaraja, Banyuasri, Kecamatan Buleleng Kabupaten Buleleng Bali. Jenis data yang digunakan dalam penelitian ini adalah data kualitatif. Untuk sumber data didapat dari data primer dan data sekunder. Data primer yaitu data yang diperoleh langsung dari sumber aslinya. Data tersebut dapat diperoleh secara langsung dari informan pada penelitian ini dengan melalui wawancara mendalam dan hasil observasi. Data yang diperoleh dari wawancara tersebut yaitu berupa pelaksanaa program tax amnesty serta tingkat keberhasilan dari program tersebut. Data sekunder merupakan pelengkap bagi data primer. Data sekunder dari penelitian ini adalah data mengenai penerimaan pajak sebelum dan sesudah adanya program tax amnesty.

Metode pengumpulan data dalam penelitian ini adalah wawancara, observasi, studi dokumentasi dan studi kepustakaan. Teknik analisis data yang digunakan dalam penelitian ini adalah metode analisis deskriptif. Metode analisis deskriptif yaitu memaparkan hasil rasio efektivitas penggunaan program pengampunan pajak (tax amnesty) dalam peningkatan penerimaan pajak dari wajib pajak orang pribadi dan wajib pajak badan di Kantor Pelayanan Pajak (KPP) Pratama Singaraja. Analisis data deskriptif dilakukan dengan membandingka data realisasi penerimaan pajak dengan target penerimaan pajak sebelum dan sesudah diterapkannya program pengampunan pajak (tax amnesty).Analisis data dilakukan melalui tiga tahapan, antara lain (1) reduksi data; (2) penyajian data; dan (3) menarik kesimpulan, sejalan dengan yang Miles, (2014).

\section{HASIL DAN PEMBAHASAN \\ Pelaksanaan Program Pengampunan Pajak (Tax Amnesty) yang dilaksanakan di KPP Pratama Singaraja}

Kantor Pelayanan Pajak Pratama Singaraja adalah lembaga pemerintahan yang bergerak dibidang pelayanan perpajakan, KPP Pratama Singaraja merupakan salah satu kantor cabang Direktorat Jenderal Pajak Departemen Keuangan. Sejak tahun 2002 Direktorat Jenderal Pajak melakukan reformasi birokrasi dan menjadi instansi percontohan reformasi birokrasi dalam memberikan pelayanan prima dan pelaksanaan good governance mengingat kedudukan DJP sebagai instansi yang sangat strategis.

$$
\text { Pengampunan pajak adalah }
$$

penghapusan pajak yang seharusnya terutang, tidak dikenai sanksi administrasi perpajakan dan sanksi pidana di bidang perpajakan, dengan cara mengungkap harta dan membayar uang tebusan. Tata cara urutan pelaksanaan tax amnesty seperti yang diatur dalam Undang-Undang No. 11 Tahun 2016, yang telah dirangkum oleh penulis sebagai berikut: (a) Langkah pertama, wajib pajak datang ke Kantor Pajak Pratama (KPP) dimana wajib pajak terdaftar untuk meminta penjelasan mengenai pengisian dan pemenuhan kelengkapan dokumen yang harus dilampirkan dalam Surat Pernyataan (SP); (b) Langkah kedua, wajib pajak melengkapi segala dokumen-dokumen yang akan digunakan yang telah dipaparkan diatas untuk mengajukan pengampunan pajak melalui Surat Pernyataan (SP), termasuk membayar uang tebusan dan pelunasan segala utang pajak seperti yang tertera dalam lampiran dokumen; (c) Langkah ketiga, wajib pajak melampikan Surat Pernyataan (SP) ke Kantor Pajak Pratama (KPP) terdaftar atau tempat lain yang telah ditentukan Menteri Keuangan; (d) Langkah keempat, wajib 
p-ISSN : 2599-1418

e-ISSN : 2599-1426

pajak mendapatkan tanda terima Surat Pernyataan (SP); dan (e) Langkah kelima, menteri atau pejabat yang telah ditunjuk atas nama menteri akan menerbitkan Surat Keterangan (SK) paling lama 10 hari kerja, terhitung sejak tanggal diterima Surat Pernyataan (SP) beserta lampirannya.

Setelah Surat Keterangan (SK) sebagai bukti keikutsertaan dalam pengampunan pajak terbit, Surat Keterangan (SK) yang telah ditandatangani kanwil tersebut akan dikirimkan kepada wajib pajak. Jika dalam 10 hari kerja menteri atau pejabat yang
Jurnal Pendidikan Ekonomi Undiksha

Volume 10 No. 1 Tahun 2018

telah ditunjuk atas nama menteri belum menerbitkan Surat Keterangan (SK), Surat Pernyataan (SP) yang telah diberikan dianggap diterima. Wajib pajak hanya dapat menyampaikan Surat Pernyataan (SP) sebanyak 3 kali selama berlakunya Undang-Undang Pengampunan Pajak.

Tugas dari Kantor Pelayanan Pajak Pratama Singaraja adalah melaksanakan tugas pokok Direktorat Jendral Pajak dalam Penerimaan Pajak Negara. Pada pelaksanaan program tax amnesty, Kantor Pelayanan Pajak Pratama Singaraja menjalankan beberapa prosedur yaitu sebagai berikut.

Tabel 1. Prosedur Pelayanan Tax Amnesty (Pengampunan Pajak) pada KPP Pratama Singaraja

\begin{tabular}{|c|c|c|}
\hline Langkah & Pelaksana & Aktivitas \\
\hline Langkah 1 & Petugas Helpdesk & $\begin{array}{l}\text { Memberikan penjelasan dan informasi } \\
\text { tentang persyaratan dan kelengkapan } \\
\text { berkas Surat Pernyataan Harta kepada } \\
\text { Wajib Pajak }\end{array}$ \\
\hline Langkah 2 & Bank Persepsi & $\begin{array}{l}\text { Membayar uang tebusan ke Bank } \\
\text { Persepsi yang ditetapkan melalui e-billing } \\
\text { menggunakan kode akun pajak (KAP). }\end{array}$ \\
\hline Langkah 2 & Petugas Penerimaan & $\begin{array}{l}\text { a. Mengoordinasikan penerimaan Surat } \\
\text { Pernyataan; } \\
\text { b. Meneliti Kelengkapan administrasi } \\
\text { Surat Pernyataan dan lampirannya, } \\
\text { yang dituangkan dalam Checklist } \\
\text { Syarat Dan Kelengkapan Surat } \\
\text { Pernyataan; dan } \\
\text { c. Meneruskan Surat Pernyataan kepada } \\
\text { Pengarah Layanan. }\end{array}$ \\
\hline Langkah 3 & $\begin{array}{l}\text { Petugas } \\
\text { Layanan }\end{array}$ & $\begin{array}{l}\text { a. Meneruskan Surat Pernyataan kepada } \\
\text { Subtim Peneliti; } \\
\text { b. Menghubungkan Wajib Pajak dengan } \\
\text { Subtim Peneliti } \\
\text { c. Menyerahkan tanda terima kepada } \\
\text { Wajib Pajak }\end{array}$ \\
\hline Langkah 4 & Petugas Peneliti & $\begin{array}{l}\text { a. Cek syarat dan kelengkapan SPH } \\
\text { b. Cek kesesuaian isian dan dokumen } \\
\text { c. Cek Kebenaran hitungan uang tebusan } \\
\text { dan pelunasannya pada hari yang } \\
\text { sama anda akan mendapatkan tanda } \\
\text { terima }\end{array}$ \\
\hline Langkah 5 & Petugas Pemberkasan & $\begin{array}{l}\text { Surat Keterangan Pengampunan Pajak } \\
\text { diterima oleh Wajib Pajak Dalam jangka } \\
\text { waktu } 10 \text { hari kerja terhitung sejak tanggal } \\
\text { tanda terima diperoleh, terbit surat } \\
\text { Keterangan Pengampunan Pajak. }\end{array}$ \\
\hline
\end{tabular}

(Sumber: Hasil Wawancara dan Observasi, 2019) 
Dalam pelaksanaan setiap kebijakan perpajakan, tentunya terdapat kendala yang dihadapi dalam proses implementasi kebijakan baik dari sisi fiskus sebagai pemungut pajak ataupun dari Wajib Pajak sebagai subjek pajak. Pelaksanaan tax amnesty pun tidak luput dari kendala yang dihadapi, hal ini disampaikan oleh Staf Bagian Informasi dan Komunikasi KPP Pratama Singaraja (Bapak Dewa Made Asta Wijaya) menyatakan, kendala yang dihadapi KPP Pratama Singaraja yang berkewenangan sebagai fiskus adalah masih rendahnya tingkat kesadaran masyarakat dalam melaksanakan kewajiban perpajakannya. Hal ini terjadi dikarenakan Wajib Pajak masih tidak mengetahui manfaat dari membayar pajak, kurangnya kepercayaan Wajib Pajak terhadap aparat pajak, dan Wajib Pajak yang telah terlanjur membayar pajak, lebih memilih hanya sekedar ikut memanfaatkan program tax amnesty daripada diperiksa oleh aparat pajak. Kesadaran wajib pajak merupakan suatu kondisi di mana wajib pajak mengetahui, memahami, dan melaksanakan ketentuan perpajakan dengan benar dan sukarela. Kesadaran wajib pajak yang tinggi dapat mendorong pemahaman dan pelaksanaan kewajiban perpajakan semakin baik sehingga dapat meningkatkan kepatuhan (Puji dan Aryani, 2016).

Sistem penerapan pemungutan pajak seperti ini memiliki keuntungan di mana kantor pajak tidak akan disulitkan dalam mengitung dan mendata jumlah pajak yang seharusnya dibayar oleh wajib pajak. Tetapi, di sisi lain penerapan sistem ini seakan-akan memberikan kesempatan bagi wajib pajak, untuk mengurangi jumlah pajak yang harus dibayar dengan cara menekan beban pajak. Penentuan nilai harta dalam Surat Pernyataan Harta dilakukan oleh wajib pajak sendiri, maka aka nada potensi bagi wajib pajak untuk menilai hartanya dibawah nilai yang sewajarnya. Hal ini tentunya menjadi kendala bagi Kantor Pelayanan Pajak karena penerimaan pajak menjadi berpotensi tidak maksimal.

Selain kendala yang dihadapi oleh Kantor Pelayanan Pajak, wajib pajak sebagai subjek pajak juga mengalami kendala dalam proses tax amnesty. Berdasarkan hasil wawancara bersama beberapa wajib pajak, mereka menyampaikan kendala yang dialami saat mengikuti tax amnesty adalah kurangnya sosialisasi yang dirasakan oleh Wajib Pajak karena pelaksanaan sosialisasi yang kurang intensif dan tidak berkelanjutan yang di lakukan oleh KPP di Singaraja. Hal ini dibuktikan bahwa wajib pajak masih terkendala masalah rumitnya birokrasi pajak seperti masih rumitnya pengisian formulir pernyataan tax amnesty dan penyiapan dokumen pendukung. Wajib pajak belum mengetahui dan memperoleh informasi yang cukup baik mengenai proses pelaksanaan tax amnesty. Kurangnya sosialisasi mengakibatkan rendahnya pengetahuan Wajib Pajak tentang peraturan perpajakan sehingga masih banyak Wajib Pajak yang belum memenuhi kewajibannya sebagai Wajib Pajak. Sosialisasi peraturan perpajakan juga masih belum menyeluruh ke setiap Wajib Pajak yang dapat menyebabkan minimnya pengetahuan Wajib Pajak tentang informasi perpajakan dan hal tersebut dapat berdampak pada penerimaan pajak negara. Selain itu, dari aspek teknis, wajib pajak mengalami kendala pada saat pembayaran uang tebusan ke Bank Persepsi yang ditunjuk oleh Kementerian Keuangan tidak membuka gerai di KPP, sehingga wajib pajak harus bolak-balik dari Bank ke KPP, wajib pajak mengharapkan Bank Persepsi berada satu atap dengan KPP pada saat program tax amnesty dilakukan sehingga dapat mempercepat proses pembayaran uang tebusan pajak.

\section{Tingkat Keberhasilan Pelaksanaan Program Pengampunan Pajak (Tax Amnesty) di KPP Pratama Singaraja}

Pengampunan pajak (tax amnesty) adalah penghapusan pajak yang seharusnya terutang, tidak dikenai sanksi administrasi perpajakan dan sanksi pidana di bidang perpajakan, dengan cara mengungkap harta dan membayar uang tebusan sebagaimana diatur dalam Undang-Undang (Undang-Undang No. 11 Tahun 2016). Pada akhirnya, diharapkan pengampunan pajak dapat mendorong 
penerimaan pajak, baik secara langsung maupun tidak langsung, karena dengan pengampunan pajak ini diharapkan wajib pajak yang selama ini tidak membayar pajak atau menyimpan asetnya di luar negeri mau melaporkan pajak dan asetnya secara transparan kepada Negara. Untuk dapat diketahui berhasil atau tidaknya pelaksanaan program tax amnesty dapat dilihat dari realisasi penerimaan pajak sesudah diterapkannya program tax amnesty.

Penerimaan pajak sebelum dilaksanakannya program tax amnesty berdasarkan data yang diperoleh dari Kantor Pelayanan Pajak (KPP) Pratama Singaraja diketahui mengalami peningkatan, dimana hal ini sesuai dengan jumlah masuknya SPT yang ada. Dilaksanakannya program tax amnesty yang dimulai pada tahun 2016 dan berakhir pada tahun 2017. Dengan demikian penerimaan pajak sebelum adanya tax amnesty diketahui dari laporan penerimaan sebelum tahun 2016 yaitu tahun 2014 dan tahun 2015 yang dapat dilihat pada tabel 2 berikut ini.

Tabel 2. Penerimaan Pajak di KPP Pratama Singaraja Sebelum dan Sesudah Tax Amnesty

\begin{tabular}{ccc}
\hline Sebelum Tax Amnesty & Target Penerimaan Pajak & $\begin{array}{c}\text { Realisasi Penerimaan } \\
\text { Pajak }\end{array}$ \\
\hline 2014 & Rp. 267.775.752.000 & Rp. 264.997.643.106 \\
2015 & Rp. 295.665.006.000 & Rp. 258.180.722.139 \\
2016 & Rp. 384.889.441.702 & Rp. 286.142.679.091 \\
2017 & Rp. 363.911.417.007 & Rp. 267.622.722.672 \\
\hline
\end{tabular}

(Sumber: Data Primer Diolah, 2019)

Pengukuran tingkat keberhasilan pelaksanaan program pengampunan pajak (tax amnesty) diukur menggunakan rasio efektivitas. Menurut Listyaningtyas ,(2012) menyatakan efektivitas diartikan seberapa jauh tercapainya suatu tujuan yang terlebih dahulu ditentukan. Suatu usaha atau kegiatan dapat dikatakan efektif apabila usaha atau kegiatan tersebut telah mencapai tujuannya. Apabila konsep efektivitas dikaitkan dengan penerimaan pajak maka efektivitas penerimaan pajak adalah kemampuan kantor pajak dalam memenuhi target penerimaan pajak berdasarkan realisasi penerimaan pajak. Artinya seberapa jauh kantor pajak dapat mencapai target penerimaan pajak yang sudah ditetapkan.

Tingkat efektivitas penerimaan Tax Amnesty dihitung dengan membandingkan antara Realisasi dan Target Penerimaan Tax Amnesty (Pengampunan Pajak) pada tahun 2015 sampai dengan tahun 2017. Persestase efektivas penerimaan Tax Amnesty digunakan sebagai tolak ukur dalam melihat tingkat keberhasilan dari penerapan Tax Amnesty (Pengampunan Pajak) pada Kantor Pelayanan Pajak Pratama Singaraja. Data persentase perbandingan realisasi dan target penerimaan pajak disajikan pada tabel 3 berikut.

Tabel 3. Efektivitas Penerimaan Pajak Selama Periode Sebelum dan Sesudah Program Tax Amnesty Pada KPP Pratama Singaraja

\begin{tabular}{cccccc}
\hline $\begin{array}{c}\text { Tahun } \\
\text { Pajak }\end{array}$ & $\begin{array}{c}\text { Jumlah VP } \\
\text { yang } \\
\text { Mengikuti TA }\end{array}$ & $\begin{array}{c}\text { Target Penerimaan } \\
\text { Pajak }\end{array}$ & & $\begin{array}{c}\text { Realisasi } \\
\text { Penerimaan Pajak }\end{array}$ & $\begin{array}{c}\text { Persentase } \\
\text { Efektivitas }\end{array}$ \\
\cline { 3 - 3 } 2015 & - & Rp. 295.665.006.000 & & Rp. 258.180.722.139 & $87,32 \%$ \\
2016 & 1.210 & Rp. 384.889.441.702 & & Rp. 286.142.679.091 & $74,34 \%$ \\
2017 & 994 & Rp. 363.911.417.007 & & Rp. 267.622.722.672 & $73,54 \%$ \\
\hline
\end{tabular}

(Sumber: data diolah, 2019) 
p-ISSN : 2599-1418

e-ISSN : 2599-1426

Berdasarkan tabel 3 diatas diketahui bahwa efektivitas penerimaan pajak pada tahun 2015, sebelum diberlakukannya program tax amnesty adalah sebesar $87,32 \%$. Kemudian, tingkat efektivitas Penerimaan pajak pada tahun 2016 setelah diberlakukannya program tax amnesty adalah sebesar $77,94 \%$ dimana penerimaan pajak melalului program Tax Amnesty ini belum memenuhi target yang di tetapkan oleh Sub Bagian Umum KPP Pratama Singaraja, walaupun dari segi persentase mengalami penurunan sebesar $12,98 \%$ namun dari segi jumlah penerimaan mengalami peningkatan $\mathrm{Rp}$. 27.961.956.952,00 dibandingkan tahun 2015 jumlah wajib pajak yang mengikuti program tax amnesty pada periode I dan II tahun 2016 sebanyak 1.210 Wajib Pajak.

Penurunan tingkat efektivitas Tax Amnesty ini juga terjadi pada periode
Jurnal Pendidikan Ekonomi Undiksha

Volume 10 No. 1 Tahun 2018

ketiga yaitu pada tahun 2017 yang hanya sebesar 73,54 \% dimana penurunan ini disebabkan karna naiknya uang tebusan yang menjadi $5 \%$, serta target penerimaan Tax Amnesty yang ditetapkan oleh KPP Pratama Singaraja yang sebesar $\mathrm{Rp}$. 363.911.417.007,00 dimana jumlah ini jauh dari target penerimaan tahun sebelumnya atau mengalami penurunan sebesar Rp. 20.978.024.695,00 serta realisasi penerimaan pajak pada tahun 2017 mengalami penurunan sebesar Rp. 18.519.956.419,00, begitu pula jumlah wajib pajak yang mengikuti program tax amnesty menurun menjadi 994 Wajib Pajak.

Kriteria penilaian efektivitas sebagai tolak ukur keberhasilan pelaksanaan program tax amnesty, dapat disajikan dalam tabel 4 . sebagai berikut

Tabel 4. Standar Efektivitas Penerimaan Pajak

\begin{tabular}{cc}
\hline Kriteria Penilaian & Persentase \\
\hline Sangat Efektif & $>100 \%$ \\
Efektif & $90-100 \%$ \\
Cukup Efektif & $80-90 \%$ \\
Kurang Efektif & $60-80 \%$ \\
Tidak Efektif & $<60 \%$ \\
\hline
\end{tabular}

(Sumber: Kepmendagri dalam Valeyati, 2013)

Hasil penilaian efektivitas Pelayanan Pajak (KPP) Pratama penerimaan pajak sebelum dan sesudah Singaraja dapat disajikan pada tabel 5 . adanya program tax amnesty pada Kantor sebagai berikut.

Tabel 5. Presentase Efektivitas Penerimaan Tax Amnesty dan Kriteria Penilaian Pada KPP Pratama Singaraja

\begin{tabular}{ccc}
\hline Tahun Pajak & Persentase Efektivitas & Kriteria Penilaian \\
\hline 2015 & $87,32 \%$ & Cukup Efektif \\
2016 & $74,34 \%$ & Kurang Efektif \\
2017 & $73,54 \%$ & Kurang Efektif \\
\hline
\end{tabular}

(Sumber: data diolah, 2019)

Berdasarkan tabel 5 diatas dapat diketahui bahwa efektivitas penerimaan pajak pada tahun 2015, sebelum implementasi tax amnesty persentasenya sebesar 87,32 \% sehingga dapat dikategorikan "cukup efektif" sesuai dengan kriteria Standar Efektivitas Penerimaan Pajak menurut Kepmendagri tahun 2013. Selanjutnya, efektivitas penrimaan pajak selama penerapan tax amnesty untuk periode pertama dan kedua pada tahun 2016 sebesar 74,34\% sehingga dapat dikategorikan "kurang efektif" sesuai dengan kriteria Standar Efektivitas Penerimaan Pajak menurut Kepmendagri tahun 2013. Kurang efektifnya program tax amnesty pada periode pertama dan kedua ini karena 
presentase diantara $60-80 \%$ dinyatakan "kurang efektif". Selanjutnya, efektivitas penerimaan pajak pada tahun 2017, pada implementasi tax amnesty periode ketiga persentasenya sebesar $73,54 \%$ sehingga dapat dikategorikan "cukup efektif" sesuai dengan kriteria Standar Efektivitas Penerimaan Pajak menurut Kepmendagri tahun 2013.

Kurang efektifnya pelaksanaan program tax amnesty yang dilihat dari persentase penerimaan pajak masih dirasa kurang efektif. Hal ini disampaikan oleh Staf Bagian Informasi dan Komunikasi KPP Pratama Singaraja (Bapak Dewa Made Asta Wijaya) bahwa hasil perhitungan efektivitas penerimaan pajak, secara keseluruhan rata - rata tingkat keberhasilan pelaksanaan tax amnesty yang diukur dengan rasio efektivitas penerimaan pajak saat diterapkannya tax amnesty pada KPP Pratama Singaraja selama tiga periode (tahun 2016-2017) dinyatakan kurang efektif atau kurang berhasil dalam meningkatkan penerimaan pajak.

\section{SIMPULAN DAN SARAN Simpulan}

Berdasarkan hasil penelitan dapat disimpulkan bahwa hasil penelitian menunjukkan (1) Prosedur pelaksanaan tax amnesty pada Kantor Pelayanan Pajak Singaraja telah sesuai dengan peraturan yang berlaku yaitu Undang-Undang No.11 Tahun 2016. Kendala yang dihadapi KPP Pratama Singaraja yang berkewenangan sebagai fiskus adalah masih rendahnya tingkat kesadaran masyarakat dalam melaksanakan kewajiban perpajakannya. Sedangkan, kendala yang dialami oleh wajib pajak yang mengikuti tax amnesty adalah kurangnya sosialisasi yang dirasakan oleh Wajib Pajak. Pelaksanaan sosialisasi yang kurang intensif dan tidak berkelanjutan yang di lakukan oleh KPP di Singaraja. (2) Tingkat keberhasilan pelaksanaan tax amnesty yang diukur dengan rasio efektivitas penerimaan pajak saat diterpakannya tax amnesty pada KPP Pratama Singaraja selama tiga periode (2016-2017) dinyatakan kurang efektif atau kurang berhasil dalam meningkatkan penerimaan pajak.

\section{Saran}

Berdasarkan penelitian yang telah dilakukan, adapun saran yang dapat diberikan yaitu (1) Bagi Wajib Pajak disarankan untuk lebih meningkatkan kesadaran akan kewajiban untuk menghitung, melaporkan dan membayar pajak yang terhutang secara benar dan diharapkan untuk lebih aktif memanfaatkan program perpajakan yang dikeluarkan oleh Dirjen pajak; (2) Bagi Kantor Pelayanan Pajak, saran yang dapat dijadikan bahan pertimbangan kepada pihak Kantor Pelayanan Pajak Pratama Singaraja dalam program tax amnesty yang berhubungan dengan tingkat keberhasilan penerapan tax amnesty terhadap penerimaan pajak, yaitu melakukan pendekatan secara langsung untuk memberikan arahan dan bimbingan terhadap Wajib Pajak yang berpotensi mengikuti program tax amnesty agar wajib pajak mengetahui jelas prosedur program tax amnesty (pengampunan pajak) dan melakukan sosialisasi yang lebih intensif baik secara langsung maupun dalam forum publik mengenai keuntungan/fasilitas yang akan diterima oleh Wajib Pajak yang memanfaatkan program tax amnesty (pengampunan pajak), maupun kerugian yang akan diterima Wajib Pajak apabila tidak memanfaatkan program tax amnesty; dan (3) Penelitian ini dilakukan hanya di KPP Pratama Singaraja di Lingkungan Kanwil DJP Provinsi Bali kurang dapat mewakili secara keseluruhan. Untuk penelitian yang akan datang dapat dilakukan di KPP Pratama lainnya yang ada di Lingkungan Kanwil DJP Provinsi Bali, sehingga mendapatkan hasil penelitian yang lebih luas.

\section{DAFTAR PUSTAKA}

Alm, James. 2009. "Do Tax Amnesties Work? The Revenue Effects of Tax Amnesties During The Transition in the Russian Federation." Journal 39: 235-53.

Listyaningtyas, Ellya Florentin. 2012. "Efektivitas Pelaksanaan 
p-ISSN : 2599-1418

e-ISSN : 2599-1426
Jurnal Pendidikan Ekonomi Undiksha

Volume 10 No. 1 Tahun 2018

Pemeriksaan Dalam Rangka

Penerimaan Negara Dari Sektor

Pajak." skripsi universitas negeri surabaya.

Miles, M.B Humberman. 2014. Qualitative Data Analysis, A Methods Sourcebook. 3rd ed. ed. Tjettjep Rohindi Rohidi. USA: Sage Publicaton.

Puji, T., \& Aryani. 2016. "Tren Penghindaran Pajak Perusahaan Manufaktur Di Indonesia Yang Terdaftar Di BEI Tahun 2001-2004." Jurnal Akuntansi 20: 375-88.

Silitonga, Erwin. 2008. Ekonomi Bawah Tanah, Pengampunan Pajak Dan Referendum. Bandung.

Sugiyono. 2012. Metode Penelitian Pendidikan (Pendekatan Kuantitatif, Kualitatif, Dan R\&D). Bandung: CV. Alfabeta.

Supramono dan Damayanti. 2010.

Perpajakan Indonesia. Yogyakarta: CV. ANDI.

Undang-Undang Republik Indonesia, Nomor 11 Tahun 2016 Tentang Pengampunan Pajak. 